\title{
救命救急センターにおける 非静脈癐性上部消化管出血患者の治療成績
}

\author{
小野寺 誠 藤野 靖久 井上 義博 菊池 哲 \\ 遠藤 重厚
}

\begin{abstract}
要旨【目的】非静脈瘤性上部消化管出血患者において搬入時間帯別と施行内視鏡専従医人数別 に再出血，入院期間の差を検討すること。【対象と方法】対象は2007年から 2011 年までの間に救 急搬送された非静脈瘤性上部消化管出血症例のうちヒータープローブ法で止血術を施行した 150 例。内訳は胃潰瘍 94 例, 十二指腸潰瘍 30 例, マロリーワイス症候群 11 例, 吻合部潰瘍 6 例, 胃 癌 4 例，その他 5 例。止血治療は，Forrestの内視鏡的出血像分類の type Ia，Ib，IIaに対して血管 の平坦化まで焼灼を続け, type IIbに対しては潰瘍底から凝血塊を剥離し，血管を認めた場合は 血管の平坦化まで燒灼を行った。治療翌朝に second look内視鏡検査を行い，ほほ全例に対して 再焼灼し止血を確認した。搬入時間が平日の午前 8 時 30 分から午後 5 時までの日勤帯群と夜間 · 日祝日の時間外群に分け, 年齢, 搬入時の Glasgow coma scale, ショック指数, 血液データ, Forrestの内視鏡的出血像分類，搬入から止血終了までの時間，輸血の有無，再出血の有無，入院 日数に関して後ろ向きにコホート研究を行った。同様に複数名の専従医が診療を行った複数群と 1 名の専従医が診療を行った場合とを比較した。【結果】搬入時間別の比較では, 搬入から止血 終了までの時間が日勤带群 $45.4 \pm 19.1$ 分，時間外群 $70.0 \pm 34.4$ 分と有意差を認めた（ $<<0.001 ） 。 一$ 方，専従医人数別の比較では搬入から止血終了までの時間に有意差を認めなかった（ $=0.058 ） 。$ 再出血と入院日数は，いずれの検討でも有意差を認めなかった。【結語】止血術の工夫により， 時間外に搬入された場合や 1 名の専従医が対応した場合であっても再出血や入院日数の延長を抑 えることが可能であった。
\end{abstract}

(日救急医会誌. 2014; 25: 1-8)

キーワード：内視鏡専従医, 内視鏡的止血時間, 再出血, 入院日数

\section{はじめに}

上部消化管出血は救急医療現場で遭遇する頻度が の高い疾患で, 30-40\%の症例が搬入時にショックに 陥っているといわれている ${ }^{1,2)}$ 。手技に卓越した消化 器内視鏡専従医（以下専従医）による迅速かつ的確 な止血処置が要求される場面であるが, これまで救

Treatment outcomes of patients with non-variceal upper gastrointestinal bleeding in emergency and critical care center 岩手医科大学救急医学講座

著者連絡先：干020-8505 岩手県盛岡市内丸 19-1

原稿受理日：2012年11月27日（12-124）
急医療現場における専従医の治療成績はほとんど報 告されていない2)。上部消化管出血のうち, 静脈瘤 出血の治療には複数の専従医の連携を要する ${ }^{3)}$ 一方 で, 内視鏡的止血術のひとつであるヒータープロー ブ法は，専従医が単独で施行しうる長所がある4) また内視鏡による緊急止血術は搬入時間帯によって は専従医が 1 名で全てを行うことがあるために止血 までの時間や再出血に関して差異が生じることが予 想される。今回, 静脈瘤出血を除いた上部消化管出 血患者において, 再出血, 入院期間の差を搬入時間 帯別と施行内視鏡専従医人数別に分け検討した。 
Table 1. Characteristics of patients.

\begin{tabular}{lcccc}
\hline & $\begin{array}{c}\text { Male } \\
(\mathrm{n}=116)\end{array}$ & $\begin{array}{c}\text { Female } \\
(\mathrm{n}=34)\end{array}$ & $\begin{array}{c}\text { Re-bleeding } \\
(\mathrm{n}=13)\end{array}$ & $\begin{array}{c}\text { Total } \\
(\mathrm{n}=150)\end{array}$ \\
\hline Hemorrhagic gastric ulcer & 75 & 19 & 9 & 94 \\
Hemorrhagic duodenal ulcer & 20 & 10 & 3 & 30 \\
Mallory-Weiss syndrome & 8 & 3 & 0 & 11 \\
Hemorrhagic anastomotic ulcer & 6 & 0 & 0 & 6 \\
Hemorrhagic gastric cancer & 3 & 1 & 0 & 4 \\
Other diseases & 4 & 1 & 1 & 5 \\
\hline
\end{tabular}

\section{対象}

2007 年より 2011 年までの 5 年間に当院高度救命救 急センターに救急搬送された非静脈瘤性上部消化管 出血症例 186 例のうち，熱凝固法のひとつである ヒータープローブ法5)で止血術を施行した 150 例を 対象とした。対象の内訳は男性116例, 女性 34例, 平均年齢 68 歳（20-95歳）である。出血源は胃潰瘍 が94例と最も多く，以下十二指腸潰瘍，マロリーワ イス症候群，吻合部潰瘍，胃癌などであった（Table 1)。Forrestの内視鏡的出血像分類6)(以下Forrest 分類) では type Ia：噴出性出血 31 例, type Ib：湧出性出血 26例, type IIa：露出血管 67 例, type IIb：凝血塊付 着26例であった。輸血は搬入時もしくは経過中にへ モグロビン值が $6.0 \mathrm{~g} / \mathrm{dl}$ 以下となった全例，もしくは 6.0-7.0g/dlの範囲で専従医が必要と判断した症例に 施行した。エンドポイントは発症から 28 日後の時点 とした。その結果, 全例生存し interventional radiology（IVR）移行例や手術移行例は認めなかった。

\section{方 法}

対象を，当施設救急外来到着の時間が平日の午前 8 時 30 分から午後 5 時までの日勤帯群と, 夜間・日 祝日の時間外群に分け, 年齢, 搬入時の Glasgow coma scale, ショック指数, 血液デー夕, Forrest分類, 搬入から内視鏡治療中に止血が確認できた時間（以 下止血終了までの時間), 輸血や再出血の有無, 入 院日数に関して後ろ向きにコホート研究を行った。 また複数名の専従医で診療を行った複数群と 1 名の
専従医が診療を行った単数群とに分け，同様に後ろ 向きにコホート研究を行った。

\section{1. 当科における診療の特徵}

\section{1）搬入から入院までの流れ}

患者搬入後, 専従医はバイタルサインの測定と血 液検査, 末梢静脈路の確保を行う。循環管理を行い バイタルサインが安定したことを確認し, 病歴聴取, レントゲン検査, 心電図検査を行う。以上の処置を 時間外の場合, 日当直医や研修医が行う。その後, 患者および家族へインフォームドコンセントを含む 各種承諾書への同意を専従医が取得する。内視鏡治 療後, 結果説明や入院指示, 内視鏡の洗浄, 後片付 けまで専従医が行う。単数群では全てを専従医が 1 名で行う。

\section{2) 止血治療法}

Forrest分類 type Ia，Ib，IIaに対して血管の平坦化 まで焼灼を続け, type IIbに対しては潰瘍底から凝 血塊を剥離し，血管を認めた場合は血管の平坦化ま で焼灼を行った。治療翌朝に second look内視鏡検 査（以下 second look）を行い，ほぼ全例に対して再 焼灼し止血を確認後, 同日昼より流動食を開始し た。平均 5 日間で全䩑まで食事をアップし, 再度内 視鏡検查で血管の消失が確認できた時点で退院許可 とした。本研究では併存疾患の治療で入院期間が延 長した症例を多く含んでいたため, 原疾患の治療が 終了した退院許可日までを入院日数と定義した。

\section{3）再出血の適応と処置}

食事開始後に再出血を認めた症例を再出血ありと 
判定し，再度ヒータープローブで止血術を行った。 翌朝 second lookで再焼灼し止血を確認後, 同日昼 より流動食を開始した。

\section{4）内視鏡専従医の待機状況および看護師のサポート状況}

当科に所属する専従医は, 本調查開始時内視鏡経 験年数が 25 年以上 1 名, 15 年以上 1 名, 10 年以上 1 名, 5 年以上 1 名の計 4 名である。いずれも住居から病 院まで車で 15 分圈内に居住しており，24時間呼び 出し可能な体制を整えている。また呼吸状態が悪化 した場合の人工呼吸管理や必要時に血液浄化療法を 含む集中治療を施行することが可能である。救急外 来看護師は搬入後からの看護，および内視鏡治療中 のバイタルサイン測定や介助を行っている。配置人 員数は時間外群では少人数となるが, 緊急時には病 棟からサポートの看護師を派遣するなどの体制を整 えている。

\section{2. 本研究における倫理的配慮}

本研究は匿名化した臨床データを用いた後ろ向き 調査であり，ヘルシンキ宣言の基本原則を遵守した。

\section{3. 統計解析}

連続変数は平均値士標準偏差で表し, 比較検討に は $\mathrm{t}$ 検定を用いた。名義変数の比較には $\chi^{2}$ 検定もし くはFisher's exact probability testを用いて解析を行っ た。有意水準両側 $5 \%$ 未満（ $\mathrm{p}<0.05 ）$ を統計学的有 意差ありと判断した。

\section{結果}

輸血は 101 例（67.0\%）に施行し，再出血は13例 (8.7\%) に認められた。

\section{1. 搬入時間別の比較}

参入基準を満たした 150 例のうち，日勤帯群は 62 例, 時間外群は 88 例であった。年齢, Glasgow coma scale, ショック指数に有意差を認めなかった。血液 検査では，白血球数が時間外群で有意に高值であっ たが，赤血球数，ヘモグロビン，血小板，尿素窒素，
クレアチニン, prothrombin time-international normalized ratio（PT-INR）に有意差を認めなかった。搬入 から止血終了までの時間は, 日勤帯群が $45.4 \pm 19.1$ 分, 専従医が自宅から呼び出され, 内視鏡治療の準 備を行う時間外群が $70.0 \pm 34.4$ 分と時間外群で有意 に長い結果であった（p<0.001）。一方, Forrest分類 や輸血・再出血の有無, 入院日数に関して2群間で 有意差を認めなかった（Table 2）。

\section{2. 専従医人数別の比較}

150 例のうち 2 名以上の専従医で診療した複数群 は98例で，単数群は 52 例であった。年齢, Glasgow coma scale, ショック指数に有意差を認めなかった。 血液検查では, 白血球数が単数群で有意に高值, へ モグロビン, 血小板数が複数群で有意に低值であっ たが, 赤血球数, 尿素窒素, クレアチニン, PTINRに有意差を認めなかった。搬入から止血終了ま での時間は, 複数群 $56.3 \pm 31.6$ 分, 単数群 $66.5 \pm 30.2$ 分と有意差を認めなかった $(\mathrm{p}=0.058)$ 。Forrest分類 や輸血・再出血の有無, 入院日数に関して2群間で 有意差を認めなかった（Table 3）。

\section{考察}

非静脈瘤性上部消化管出血患者は，時間外に搬入 された場合，止血までの時間が有意に長い結果で あったが, 再出血の頻度や入院日数に有意差を認め なかった。

今回，止血終了までの時間は搬入時間別の検討で 平均 25 分の差を認めた。時間外における止血時間 が有意に延長した要因として専従医が連絡を受け， 自宅から病院まで移動する時間や内視鏡準備に要し た時間が反映されていると考えられた。25分とい う時間差は臨床的に大きな差と言えないが，時間外 群 88 例中 33 例を占める Forrest 分類 type Ia や Ib 症例 では時に致命的となる可能性がある。しかし専従医 の待機状況や看護師のサポート体制のほか, 専従医 が1名であっても施行可能な止血法を導入すること で, 再出血や入院期間の延長を抑えるこが可能で 
Table 2. Comparison by time of arrival at the hospital.

\begin{tabular}{lccc}
\hline & $\begin{array}{c}\text { Day-shift group } \\
(\mathrm{n}=62)\end{array}$ & $\begin{array}{c}\text { After-hour group } \\
(\mathrm{n}=88)\end{array}$ & $p$ value \\
\hline Age $($ years) & $66.0 \pm 14.2$ & $68.6 \pm 14.3$ & 0.276 \\
Glasgow coma scale & $14.9 \pm 0.2$ & $14.8 \pm 0.7$ & 0.064 \\
Shock index $(>1 /<1)$ & $13 / 49$ & $20 / 68$ & 0.798 \\
WBC $(/ \mu \mathrm{l})$ & $9,418 \pm 3,871$ & $10,866 \pm 4,093$ & 0.031 \\
$\mathrm{RBC}\left(\times 10^{4} / \mu \mathrm{l}\right)$ & $271.5 \pm 91.1$ & $291.4 \pm 96.1$ & 0.203 \\
$\mathrm{Hb}(\mathrm{g} / \mathrm{dl})$ & $8.3 \pm 2.6$ & $9.0 \pm 3.2$ & 0.180 \\
Platelet $\left(\times 10^{4} / \mu \mathrm{l}\right)$ & $24.5 \pm 9.2$ & $25.4 \pm 10.3$ & 0.576 \\
BUN $(\mathrm{mg} / \mathrm{dl})$ & $43.7 \pm 23.1$ & $46.0 \pm 24.8$ & 0.565 \\
Cr $(\mathrm{mg} / \mathrm{dl})$ & $1.1 \pm 1.3$ & $1.3 \pm 1.7$ & 0.377 \\
PT-INR & $1.4 \pm 2.2$ & $1.5 \pm 2.1$ & 0.835 \\
& & & 0.881 \\
Forrest classification (Ia, Ib/IIa, IIb) & $24 / 38$ & $33 / 55$ & $<0.001$ \\
Time from arrival at the hospital & $45.4 \pm 19.1$ & $70.0 \pm 34.4$ & 0.658 \\
until completion of hemostasis (min.) & $43 / 19$ & $58 / 30$ & 0.094 \\
Erythrocyte transfusion (present/absent) & $2 / 60$ & $11 / 77$ & 0.981 \\
Re-bleeding (present/absent) & $6.9 \pm 3.0$ & $6.9 \pm 3.1$ & \\
Length of hospital stay (days) & & & \\
\hline
\end{tabular}

WBC: white blood cell, RBC: red blood cell, Hb: hemoglobin, BUN: blood urea nitrogen, Cr: creatinine, PT-INR: prothrombin time international normalized rate

Table 3. Comparison by number of endoscopists.

\begin{tabular}{lccc}
\hline & $\begin{array}{c}\text { Multiple-endoscopist } \\
\text { group }(\mathrm{n}=98)\end{array}$ & $\begin{array}{c}\text { Single-endoscopist } \\
\text { group }(\mathrm{n}=52)\end{array}$ & $p$ value \\
\hline Age (years) & $67.4 \pm 13.7$ & $67.8 \pm 15.4$ & 0.867 \\
Glasgow coma scale & $14.7 \pm 1.0$ & $14.8 \pm 0.8$ & 0.660 \\
Shock index $(>1 /<1)$ & $25 / 73$ & $8 / 44$ & 0.110 \\
WBC $(/ \mu \mathrm{l})$ & $9,631 \pm 3,821$ & $11,469 \pm 4,239$ & 0.008 \\
RBC $\left(\times 10^{4} / \mu \mathrm{l}\right)$ & $272.0 \pm 89.7$ & $304.0 \pm 100.0$ & 0.054 \\
Hb $(\mathrm{g} / \mathrm{dl})$ & $8.4 \pm 2.8$ & $9.4 \pm 3.3$ & 0.041 \\
Platelet $\left(\times 10^{4} / \mu \mathrm{l}\right)$ & $23.7 \pm 8.9$ & $27.7 \pm 11.0$ & 0.018 \\
BUN $(\mathrm{mg} / \mathrm{dl})$ & $44.4 \pm 22.5$ & $46.4 \pm 27.1$ & 0.627 \\
Cr $(\mathrm{mg} / \mathrm{dl})$ & $1.1 \pm 1.3$ & $1.3 \pm 1.7$ & 0.325 \\
PT-INR & $1.1 \pm 1.2$ & $1.4 \pm 2.1$ & 0.961 \\
& & & 0.932 \\
Forrest classification (Ia, Ib/IIa, IIb) & $37 / 61$ & $20 / 32$ & 0.058 \\
Time from arrival at the hospital & & $66.5 \pm 30.2$ & 0.711 \\
until completion of hemostasis (min.) & $56.3 \pm 31.6$ & $34 / 18$ & 0.344 \\
Erythrocyte transfusion (present/absent) & $67 / 31$ & $6 / 46$ & 0.739 \\
Re-bleeding (present/absent) & $7 / 91$ & $6.7 \pm 2.7$ & \\
\hline
\end{tabular}

WBC: white blood cell, RBC: red blood cell, Hb: hemoglobin, BUN: blood urea nitrogen, Cr: creatinine, PT-INR: prothrombin time international normalized rate 
あったと考えられた。一方，専従医人数別の検討で は止血終了までの時間差は平均 10 分であった。こ の理由として当施設の特徵である搬入から入院まで の流れや専従医による止血法が確立していることか ら, 専従医が1名であっても複数名の専従医の場合 と同等に迅速な止血術を施行しうると考えられた。 上野ら ${ }^{2)} は ， 70$ 例の上部消化管出血性ショック症例 の検討で搬送から緊急内視鏡検査開始まで平均 45 分と報告している。我々は, 消化管出血の診療にお いて最も重要なことは迅速な止血処置の完遂と考え ている。今回の検討症例ではショック指数が良好な 症例が多かったため上野らの検討と一概に比較はで きないが，日勤帯における止血終了までに要した時 間が平均 45 分であったことから，迅速な流れの上 で止血術が達成できたと考えられる。

再出血は $8.7 \%$ によれた。一般的に, 内視鏡に よる初回止血後の再出血率は $10 \%$ 程度と言われて (る7)。その一方で, 活動性出血を認める例や露出 血管を伴う例に止血術を行わない場合の再出血率は 40-50\%と言われている ${ }^{2,8)}$ 。夜間や休日に搬入され た症例を含めた今回の検討で，再出血の頻度がこれ までの報告と比較して低い理由の第一に専従医間の 連携が考えられる。本調査開始時, 内視鏡経験年数 が10年以上の3名の専従医の間で治療方法を統一し， 経験年数の少ない専従医が止血術を行う際には上級 医の指導の下に治療を行った。このことは時間外の 搬入症例に対しても同様であり，専従医間による技 術差を可能な限り縮小することで良好な治療成績を あげたと思われる。第 2 に，止血術の適応を広げた ことである。一般的に内視鏡治療の適応は Forrest 分類の type Ia，Ib，IIa例である ${ }^{9-11)}$ 。当科では再出 血の予防目的に type IIbの出血例に対しても凝血塊 を剥離した上で責任血管を明らかにし，血管の消失 を確認できるまで十分に時間をかけて焼灼した。こ の結果, type IIbに扔ける再出血に対しても予防で きた可能性がある。さらに再出血率の低下を目的と した second lookの徹底を行ったことである ${ }^{12)}$ 。 second look は再出血の可能性の高い Forrest分類の type
Ia，Ib，IIaに対して止血処置後 24 時間以内に行う ことが望ましいとされている ${ }^{13)}$ 。また second look時 の追加止血処置は再出血や新生出血率を低下させる ことが知られている ${ }^{14)}$ 。当科では, 全症例に対して 翌朝に second lookを行い, 例え止血状態であって も止血確認のため追加焼灼を行った。

以上, 治療法の統一や止血適応の拡大, second lookに扮ける追加焼灼が搬入時間や専従医人数に左 右されず再出血を予防できた理由と考える。

内視鏡的止血術には，ヒータープローブ法の他に， エピネフリン局注法，エタノール局注法，クリップ 法がある。これらの治療効果に差はみられない 15,16$)$ とされる一方で, Sungら ${ }^{17)}$ はクリップ法と他の止血 法を比較したメタアナリシスを行い, クリップ法が 局注法と比較して再出血率や手術移行例が有意に低 かったと報告している。しかしクリップ法は内視鏡 治療者と介助者が協力して止血操作にあたるため, 2 人の協調性が重要であり, 病変が接線方向の場合, 止 血が困難であるという問題点が指摘されている7,18,19)。

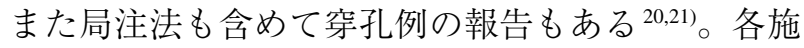
設では，それぞれの止血法の特徵を把握した上で得 意とする治療法を選択するべきであるが，当セン ターではヒータープローブを用いて長年治療を行っ ており, 出血性胃潰瘍の場合は $30 \mathrm{~J}$, それ以外の疾患 に関しては15-20Jで焼灼している22)。本法を採用し ている理由は，(1)手技が簡便であること，(2)接線方 向の病変に対して止血可能であること, (3)止血操作 が1名で行えることである。その結果, 時間外であっ ても1名で止血術を行うことが可能で, 当センター の最終止血率は胃潰瘍 $99.5 \%$, 十二指腸潰瘍 $94.9 \%$ と なっている ${ }^{23)}$ 。現在, 救急医療現場における問題の ひとつに人員不足がある。とくに夜間は専従医やス タッフの確保が困難であることから止血処置ができ ない医療機関が増加している。今回, 初期診療から 入院に至るまで全てを1名で行った単数群と複数群 との間に再出血に関して有意差を認めなかったこと は, 今後, 少人数により施行可能なシステムの構築 につながると考えられた。 
入院日数は搬入時間別，専従医人数別で有意差を 認めず平均約 7 日であった。朝倉ら ${ }^{24)}$ は 123 例の出 血性潰瘍症例の在院日数は平均 16.7 日と報告し, 高 橋ら 25) はクリニカルパスを用いた出血性胃十二指腸 潰瘍 32 例の平均在院日数を 10.7 日と報告している。 またIwamoto ら ${ }^{26)}$ は胃十二指腸潰瘍 1,041 例を対象に 低用量アスピリン服用群，非ステロイド系抗炎症剂 服用群，いずれも服用していないコントロール群と の比較を行っている。その結果，平均入院期間はコ ントロール群が最も短く 14.2 日と報告している。今 回の検討では, 入院日数の定義を内視鏡的に再出血 の危険がなく退院許可が出た日までと定義したため に，これまでの報告と一概に比較はできないが，止 血方法の工夫により再出血の頻度が低下し, 入院期 間の延長を抑えることが可能となったと思われた。

IVRや手術移へ移行した症例は今回の検討では認 めなかった。これまでに上部消化管出血の内視鏡治 療困難例のうち IVR 移行例は $1-4 \%{ }^{18,19,27)}$, 手術移行 例は1-2\% ${ }^{7,18,27)}$, 死亡例は1-2\% $\%^{7,18)}$ と報告されている。 当科におけるIVRや手術移行例が低い理由には，止 血術の適応を拡大したことや second look の徹底によ る再出血の予防のほか, 本文には述べていないが拍 動を伴う露出血管径が $3 \mathrm{~mm}$ 以上の十二指腸潰瘍症 例では仮性動脈瘤の可能性が高いと判断し, 即 IVR による治療を選択したことにある。そのほか, 放射 線科の協力による 1 時間以内のIVRや外科医による 緊急手術が可能となるバックアップ体制を整えてい ることも重要と考えられる。

白血球数は時間外群や単数群で有意に高值であっ た。白血球は急性出血の際に増加すると言われてい る ${ }^{28)}$ 。今回の検討で時間外群や単数群で白血球数が 増加した理由は明らかではないが, これらの群には 出血から短時間で搬入された症例が多く含まれてい る可能性がある。またへモグロビンと血小板は複数 群で有意に低下していた。血小板は出血に伴い低下 することが知られている ${ }^{29,30)}$ が，いずれの低下も軽 度であり臨床的な意味は小さいと考えられる。

今回の検討の限界として軽症例が多いことが挙げ
られる。当センターは 24 時間緊急内視鏡が可能な 体制を構築していることから，発症から短時間で搬 入された症例が多かったことが原因と考えられる が，今後重症例も含めた検討が必要である。

\section{結語}

専従医間での治療法の統一, 止血適応の拡大, second lookにおける再焼灼により，時間外に搬入された 場合や 1 名の専従医が対応した場合であっても再出 血や入院日数の延長を抑えることが可能であった。

この論文の要旨は, 第 40 回日本救急医学会総会・学 術集会（京都）にて発表した。

本研究に抢ける利益相反はない。

\section{文献}

1) 房本英之: ショックを伴う吐血・下血. 救急医. 1999; 23: 757-65.

2) 上野幸廣, 阪本雄一郎, 松本尚, 他: 救命救急センター専 従医による上部消化管出血に対する治療成績についての 検討. 日臨救急医会誌. 2006; 9: 444-9.

3) 小原勝敏, 引地拓人, 高木忠之, 他: 内視鏡的治療 内視鏡 的効果療法 (EIS) EO - AS 併用法. 消臨. 2006; 9: 382-8.

4) 井上義博, 藤野靖久, 小野寺誠, 他: 上部消化管非静脈瘤 出血に対する緊急内視鏡. 消化器内科. 2012; 55: 545-52.

5) Protell RL, Rubin CE, Auth DC, et al: The heater probe: a new endoscopic method for stopping massive gastrointestinal bleeding. Gastroenterology. 1978; 74: 254-62.

6) Forrest JA, Finlayson ND, Shearman DJ: Endoscopy in gastrointestinal bleeding. Lancet. 1974; 7877: 394-7.

7) 今枝博之, 細江直樹, 柏木和弘, 他: 上部消化管出血（非 静脈瘤性出血）に対する内視鏡的止血のコッ：困難例の 対処法. Gastroenterol Endosc. 2012; 54: 2256-68.

8) Laine L, Peterson WL: Bleeding peptic ulcer. N Engl J Med. 1994; 331: 717-27.

9) Heldwein W, Schreiner J, Pedrazzoli J, et al: Is the Forrest classification a useful tool for planning endoscopic therapy of bleeding peptic ulcers? Endoscopy. 1989; 21: 258-62.

10) 日本消化器病学会編: 消化性潰瘍診療ガイドライン.出 血性胃潰瘍. 出血性十二指腸潰瘍一内視鏡的治療. 南江 堂, 東京, 2009, p1-15.

11) Barkun AN, Bardou M, Kuipers EJ, et al: International consensus recommendations on the management of patients with nonvariceal upper gastrointestinal bleeding. Ann Intern Med. 2010; 152: 101-13. 
12) Chiu PW, Lam CY, Lee SW, et al: Effect of scheduled second therapeutic endoscopy on peptic ulcer rebleeding: a prospective randomized trial. Gut. 2003; 52: 1403-7.

13) 日本消化器内視鏡学会卒後教育委員会編: 消化器内視鏡 ハンドブック. 高木敦司, 松川正明, 西元寺克禮: 緊急内視 鏡. 第1版. 日本メデイカルセンター, 東京, 2012, p81-6.

14) 浅木茂: 高齢者上部消化管出血の救急診療. 老年消病. 2000; 12: 121-6.

15) Sacks HS, Chalmers TC, Blum AL, et al: Endoscopic hemostasis. An effective therapy for bleeding peptic ulcers. JAMA. 1990; 264: 494-9.

16) Shimoda R, Iwakiri R, Sakata H, et al: Evaluation of endoscopic hemostasis with metallic hemoclips for bleeding gastric ulcer: comparison with endoscopic injection of absolute ethanol in a prospective, randomized study. Am J Gastroenterol. 2003; 98: 2198-202.

17) Sung JJ, Tsoi KK, Lai LH, et al: Endoscopic clipping versus injection and thermo-coagulation in the treatment of non-variceal upper gastrointestinal bleeding: a meta-analysis. Gut. 2007; 56: 1364-73.

18）阪口正博,高尾美幸,橋本貴史,他: 当院における 10 年間 の上部消化管出血治療の臨床的検討. Gastroenterol Endosc. 2010; 52: 2678-86.

19) 比嘉晃二, 山口康晴, 青木圭, 他: 高齢者出血性消化性潰瘍 に対する内視鏡止血術の検討. 日消誌. 2011; 108: 418-28.

20) 赤松泰次, 横澤秀一, 井上勝朗, 他: 「上部消化管」治療 内 視鏡止血術 First Choice, Second Choice. 消内視鏡. 2006; 18: 694-7.
21) 森山友章, 望月雅恵, 石岡邦啓, 他: 十二指腸息室出血の 2例. 消内視鏡. 2008; 20: 1735-41.

22) 井上義博, 藤野靖久, 小野寺誠, 他: 薬剂による消化管出 血に対する治療 内視鏡的止血術の適応と手技 止血困難 例への対応を含めて上部消化管出血. 消臨. 2009: 12: 280-4.

23) 井上義博, 今井聡子, 小野寺誠, 他: 当科における消化管出 血に対する内視鏡止血の現況. 消内視鏡. 2005; 17: 198791.

24) 朝倉泰, 今井幸紀, 伊東洋, 他: 出血性潰瘍の疫学. 埼玉 医会誌. 2003; 38: 217-20.

25) 高橋周史, 河田英里, 平田育大, 他: 出血性胃十二指腸潰瘍 に対するクリニカルパス作成の試み（第二報）アルゴリ ズムパスへの進化. 日クリニカルパス会誌. 2004; 6: 23-9.

26) Iwamoto J, Mizokami Y, Shimokobe K, et al: Clinical features of gastroduodenal ulcer in Japanese patients taking low-dose aspirin. Dig Dis Sci. 2010; 55: 2270-4.

27) 伊藤重彦, 轟木秀一, 木戸川秀生: 胃十二指腸潰瘍出血の 治療戦略 特にインターベンションと手術療法を中心に。 日救命医療会誌. 2006; 20: 3-9.

28）青木定夫：血液疾患へのアプローチ【白血球系の異常】 白血球数の増加. Medicina. 2008; 45: 2202-5.

29）小関一英, 鈴木忠, 坂本照夫, 他: 救急領域における血小 板減少症 Thrombocytopenia-Outcome-Registration Prospective（THORP） Study報告.バイオメデ. 2003; 13: 73-82.

30) 丸藤哲, 澤村淳, 早川峰司, 他: 救急集中治療における血 小板・凝固線溶系モニタリングの実際.日救急医会誌. 2009; 20: 1-15. 


\author{
ABSTRACT \\ Treatment outcomes of patients with non-variceal upper gastrointestinal bleeding \\ in emergency and critical care center \\ Makoto Onodera, Yasuhisa Fujino, Yoshihiro Inoue, Satoshi Kikuchi \\ Shigeatsu Endo \\ Department of Emergency Medicine, Iwate Medical University, School of Medicine
}

Objective: To examine the differences in rebleeding and length of hospital stay in patients with non-variceal upper gastrointestinal bleeding by time of arrival at the hospital and by number of endoscopists involved.

Patients and Methods: The subjects were 150 patients with non-variceal upper gastrointestinal bleeding who required emergency transport between 2007 and 2011 and who had undergone endoscopic hemostasis using a heater probe. They consisted of 94 patients with gastric ulcer, 30 patients with duodenal ulcer, 11 patients with MalloryWeiss syndrome, 6 patients with anastomotic ulcer, 4 patients with gastric cancer, and 5 patients with other diseases. Hemostasis involved cauterization of the vessel until flattened for types Ia, Ib, and IIa patients in the Forrest endoscopic classification of bleeding. For type IIb patients, the clot was detached from the base of the ulcer. If a vessel was observed, it was cauterized until flattened. A second-look endoscopy was performed the next morning after treatment. Almost all patients underwent recauterization, and hemostasis was confirmed. The patients were divided into two groups by time of arrival: a group transported during a day shift (8:30-17:00) on weekdays (day-shift group) and a group transported after hours (nighttime, Sundays, and holidays) (after-hour group). A retrospective cohort study was conducted on the age of patients, Glasgow coma scale upon arrival, shock index, blood test data, Forrest endoscopic classification of bleeding, time from arrival until completion of hemostasis, blood transfusion or no transfusion, absence or presence of rebleeding, and length of hospital stay. Similarly, analysis was conducted on patients divided into two groups by number of endoscopists who examined and treated the patients: a group in which multiple endoscopists were involved (multiple-endoscopist group) and a group in which a single endoscopist was involved (single-endoscopist group).

Results: The time from arrival until completion of hemostasis was $45.4 \pm 19.1 \mathrm{~min}$ for the day-shift group and $70.0 \pm$ $34.4 \mathrm{~min}$ for the after-hour group, indicating a significant difference $(\mathrm{p}<0.001)$. The multiple-endoscopist group and single-endoscopist group showed no significant difference in the time from arrival until completion of hemostasis ( $\mathrm{p}=0.058)$. Neither the two shift groups nor the two endoscopist groups showed any significant difference in rebleeding or length of hospital stay.

Conclusion: Even when the patients arrived at the hospital during after hours or when they were examined and treated by a single endoscopist, it was possible to minimize rebleeding and length of hospital stay by modification of hemostatic treatment.

(JJAAM. 2014; 25: 1-8)

Keywords: gastrointestinal endoscopists, time to hemostasis, re-bleeding, length of hospital stay

Received on November 27, 2012 (12-124) 